ROCZNIKI PEDAGOGICZNE

Tom 11(47), numer 2 - 2019

DOI: http://dx.doi.org/10.18290/rped.2019.11.2-9

JOANNA MAJCHRZYK-MIKUŁA

BARBARA GRABARCZYK

\title{
PROFILAKTYKA LOGOPEDYCZNA W PRAKTYCE NAUCZYCIELA EDUKACJI WCZESNOSZKOLNEJ
}

\section{WSTĘP}

Prawidłowe funkcjonowanie człowieka możliwe jest dzięki nabyciu umiejętności nadawania, przetwarzania i odbierania dźwięków mowy. Umiejętności, które warunkują prawidłowe nabywanie języka, rozpoczynają się wraz z momentem zapłodnienia komórki jajowej przez plemnik, to uwarunkowania genetyczne, a także pierwsze doświadczenia czuciowe płodu. Każde dziecko posiada określone predyspozycje, zaprogramowane genetyczne możliwości, a także warunki środowiskowe, które umożliwiają prawidłowe nabywanie kolejnych struktur systemu językowego (Cieszyńska, Korendo, 2015).

Za pomocą mowy możliwe jest przekazywanie znaczeń i wpływanie na własne zachowania lub zachowania innych ludzi. To niezaprzeczalnie ważna umiejętność, którą posługuje się gatunek ludzki. Każdy człowiek zna kilka tysięcy słów, nawet do stu tysięcy, a także różnorodne powiązania między nimi (homonimy, wyrazy bliskoznaczne), reguły gramatyczne i dynamikę rozwoju, na którą wpływają zmiany społeczne, kulturalne, polityczne (Nęcka, Orzechowski, Szymura, 2006).

Każde dziecko posiada umiejętność nadawania mowy, najważniejszym wyznacznikiem, który występuje podczas narodzin, jest płacz. Noworodek do komunikacji stosuje przypadkowe dźwięki. Krzyki, piski, sylaby i ich ładunek emocjonalny kształtuje świadomość i istotę komunikacji. W miarę rozwoju umiejętności ulegają przekształceniom, udoskonaleniom. Już od dziewiątego

Dr hab. JoAnna MajchrzYK-MikUŁA, prof. UJK - Instytut Nauk Pedagogicznych, Wydział Nauk Społecznych, Uniwersytet Jana Kochanowskiego w Kielcach; e-mail: drasma@wp.pl

Mgr BARBARA GrabARCZYK - Prywatny Gabinet Logopedyczno-Terapeutyczny „uczę gAAdaĆ”, Radomsko; e-mail: bar.grabarczyk2019@gmail.com 
miesiąca życia dzieci rozumieją intencjonalność słów, poznają nowe dźwięki. Piąty i szósty rok życia określany jest jako ostateczny czas kształtowania się systemu językowego. Sześciolatek powinien realizować wszystkie dźwięki polszczyzny, znać podstawowe zasady gramatyczne, budować złożone wypowiedzi słowne o określonym ładunku emocjonalnym, adekwatnym do sytuacji (Cieszyńska, Korendo, 2015). Rozwój mowy nabiera specjalnie dużego znaczenia, gdy dziecko rozpoczyna naukę $\mathrm{w}$ szkole. $\mathrm{Na}$ tym etapie powinno ono prawidłowo wypowiadać wszystkie głoski języka polskiego, ale także umieć poprawnie budować wypowiedzi słowne.

\section{WADY WYMOWY U DZIECI W WIEKU WCZESNOSZKOLNYM}

$\mathrm{Z}$ roku na rok nasila się niepokojąca, wzrastająca tendencja występowania zaburzeń i wad wymowy wśród dzieci i młodzieży. Zazwyczaj przyjmuje się, że u sześcioletniego dziecka rozwój mowy powinien być już zakończony. Nie zawsze jednak tak się dzieje, zwłaszcza jeżeli trudności w wymawianiu głosek przeciągają się do końca okresu przedszkolnego lub występują jeszcze w młodszym wieku szkolnym. W tej sytuacji można mówić o zahamowaniu lub opóźnieniu w rozwoju mowy, powszechnie zwanym opóźnieniem rozwoju mowy (ORM), który wynika z powolnej mielinizacji włókien nerwowych, osłabieniu napięcia mięśniowego w obrębie aparatu artykulacyjnego, upośledzenia umysłowego.

Zaburzenia mowy to szerokie pojęcie obejmujące wszelkie nieprawidłowości w wymawianiu głosek, zmianę ich brzmienia najczęściej poprzez zastępowanie głosek trudnych do wymówienia głoskami łatwiejszymi lub opuszczanie ich. Najczęściej występującymi wadami wymowy wśród dzieci w wieku wczesnoszkolnym jest: sygmatyzm, rotacyzm, mowa bezdźwięczna, kappacyzm, lambdacyzm.

Sygmatyzm to najczęściej spotykane zaburzenie u dzieci, inaczej zwane seplenieniem. Polega na nieprawidłowej artykulacji głosek s, z, c, dz, lub sz, ż, cz, dż oraz ś, ź, ć, dź. Wiele dzieci dotyka sygmatyzm interdentalny, czyli seplenienie międzyzębowe (mysz - mys, myś; szafa - safa, śafa; żaba - zaba, źaba). W zależności od miejsca wadliwej artykulacji wyróżniamy najczęściej spotykany sygmatyzm międzyzębowy, polegający na nieprawidłowym ułożeniu języka, który jest spłaszczony i wysuwa się między zęby, a powietrze rozprasza się po całej powierzchni, drugim popularnie występującym jest sygmatyzm wargowo-zębowy, dolne siekacze stykają się z górną wargą lub górne siekacze z dolną wargą, język nie bierze udziału w artykulacji. Występuje także sygmatyzm boczny, który 
polega na emitowaniu powietrza $\mathrm{z}$ jednej strony lub z obu stron, a nie w linii prostej. Sygmatyzm przyzębowy polega na zbliżaniu się szerokiego języka do wewnętrznej strony siekaczy. Rzadziej spotykany jest sygmatyzm świszczący, krtaniowy, gardłowy, nosowy (Grabias, Kurkowski, 2014).

Rotacyzm, obok sygmatyzmu, to kolejna często spotykana wada, która polega na zaburzonej, nieprawidłowej artykulacja głoski r, która może być artykułowana jako 1 lub j (zjawisko to nosi nazwę susbtytucji). Wyróżnić możemy r języczkowe (tzw. francuskie), które jest najczęstszą formą rotacyzmu, wymowa polega na wibracji języczka będącego zakończeniem podniebienia miękkiego. Język pozostaje bierny. Niekiedy $\mathrm{r}$ wymawiane jest nieprawidłowo: wargowo, policzkowo, tylnojęzykowo, krtaniowo, nosowo, świszcząco.

Mowa bezdźwięczna polega na zastępowaniu głosek dźwięcznych odpowiednimi głoskami bezdźwięcznymi, np.: zamiast b dziecko wymawia p (np. zamiast bułka - półka), zamiast głoski d wymawiane jest t (domek - tomek), głoska w wymawiana jest jako głoska $\mathrm{f}$ (wafel - fafel).

Kappacyzm - polega na wadliwej artykulacji głoski k (kura-tura).

Gammacyzm - polegający na wadliwej artykulacji głoski g (góra - dóra; gitara - ditara).

Lambdacyzm - to wadliwa artykulacja głoski 1 (lalka - jajka; las - jas) (Sołtys- Chmielowicz, 2016).

Wyróżnić można również wady, które polegają na nieprawidłowej realizacji dźwięku:

- mogilalie (elizja dźwięku) - polega na braku realizacji danej głoski dźwięcznej (koza-koa, góra-óra, woda-oda),

- paralalie (substytucja dźwięku) - jest zastępowanie jednej głoski dźwięcznej inną głoską bezdźwięczną (woda - fota, żaba - szaba, dom - tom).

Dzieci do około 7. roku życia powinny w prawidłowy sposób realizować wszystkie głoski przedniojęzykowo-dziąsłowe, czyli sz, ż, cz, dż i r (Skorek, 2001).

Powyższe zaburzenia mowy bardzo często są przyczyną wielu trudności napotykanych na drodze edukacji ucznia. Zazwyczaj są to kłopoty w nauce. Według badań prowadzonych w Polsce, odsetek dzieci z zaburzeniami mowy był znacznie wyższy wśród uczniów z różnego typu niepowodzeniami szkolnymi (30-38\%) w różnych klasach, przy czym wśród uczniów z trudnościami czytania i pisania wzrastał on do 40-50\%, a nawet w niektórych grupach badanych wzrósł on do $81 \%$ (Bogdanowicz, Szewczyk, 2011). Statystyki te wskazują na istnienie związku przyczynowego między występowaniem wad wymowy a trudnościami szkolnymi - zwłaszcza w nauce czytania i pisania. Wady wymowy utrudniają 
dziecku nie tylko rozwój mowy, lecz również naukę czytania, pisania, a nawet liczenia, rzutuje na przyszłość dziecka, na jego możliwość osiągania sukcesów szkolnych. Wszystkie zaburzenia negatywnie wpływają na kształtowanie się osobowości dziecka, a w szczególności na kontakty społeczne i poznawanie świata. Nieprawidłowy rozwój może mieć większy lub mniejszy wpływ na umiejętności budowania prawidłowych relacji z dorosłymi i rówieśnikami (Minczakiewicz, 2015). Uczeń, który wstępuje w szkolne mury, wchodzi w wiele nieznanych mu dotąd ról, dlatego niezbędne są umiejętności, które pozwalają na swobodne wyrażanie uczuć i myśli. Zaburzenia prawidłowego procesu nabywania mowy mają wpływ w późniejszym czasie na ograniczenia rozwoju społecznego, opóźniają rozwój intelektualno-poznawczy, emocjonalno-społeczny. Wady wymowy mogą wywoływać niekorzystne zmiany w osobowości, np. brak wiary w siebie, depresję, niski poziom samoakceptacji (Sołtys-Chmielowicz, 2008). W klasie szkolnej dzieci bezpodstawnie traktowane są negatywnie, są „niezauważane”, pełnią rolę „kozłów ofiarnych”, są nieakceptowane przez kolegów, pomijane przy nagrodach (Kurcbart, 2010). Trudno nie zgodzić się z twierdzeniem, że uczniowie z zaburzeniami w rozwoju mowy zazwyczaj źle funkcjonują w szkole. Najczęściej poniżej swoich możliwości.

Jak można zauważyć, problematyka zaburzeń artykulacyjnych i wad wymowy jest dosyć szerokim i trudnym zagadnieniem głównie ze względu na brak zrozumienia wagi problemu ze strony rodziców, ale również nauczycieli. Zatem, aby terapia mowy powiodła się, konieczne jest wspólne działanie poradni, szkoły i domu. Należy pamiętać, że zagwarantowanie dzieciom i młodzieży warunków do harmonijnego rozwoju mowy, sprawności językowej i możliwie najpełniejszych kompetencji w zakresie komunikacji interpersonalnej jest najlepszą inwestycją na przyszłość.

\section{WSPÓŁPRACA LOGOPEDÓW I NAUCZYCIELI W REALIZACJI WTÓRNEJ PROFILAKTYKI LOGOPEDYCZNEJ W EDUKACJI WCZESNOSZKOLNEJ}

Diagnoza i terapia wad wymowy oraz umiejętności komunikacyjnych mieści się w zakresie zadań logopedy, obok opieki logopedycznej, szczególnie ważna jest profilaktyka, która powinna rozpocząć się już w edukacji przedszkolnej (Węsierska, 2007). W ogólnym znaczeniu profilaktyka to działania, które nie dopuszczają do wypadków, uszkodzeń lub katastrof. Pojęcie kojarzone jest w szczególności z naukami medycznymi, w tym ujęciu oznacza wszystkie 
działania mające na celu zapobieganie chorobom, dzięki ich wczesnemu wykrywaniu i leczeniu (Okoń, 1996). Dla logopedów profilaktyka to kształtowanie prawidłowej mowy poprzez dbanie o właściwą stymulację dzieci od najwcześniejszego okresu życia (Węsierska, 2012). Profilaktyka powinna mieć ścisły i nierozerwalny związek z promocją zdrowia. W zakresie działań należy uwzględnić formy aktywności, które upowszechniają informacje na temat zaburzeń komunikacyjnych, objawów oraz czynności, które zapobiegają ich powstawaniu (Węsierska, 2012). Treści, zalecane do upowszechniania wśród rodzin dzieci uczęszczających do klas I-III, powinny obejmować:

- stymulację rozwoju mowy i języka;

- objawy zakłóceń lub zaburzeń rozwoju mowy;

- działania związane z higieną głosu dziecka;

- objawy rozwojowych wad wymowy (niepłynności mówienia);

- rodzaje placówek i określenie zadań poszczególnych grup specjalistów pracujących z dziećmi z wadami wymowy (Węsierska, 2012).

Skuteczna profilaktyka logopedyczna wymaga od logopedy ścisłej współpracy $\mathrm{z}$ rodzicami dzieci $\mathrm{w}$ wieku wczesnoszkolnym, a także z kadrą pedagogiczną szkoły, w szczególności z wychowawcami. Obejmować powinna: konsultacje, szkolenia, kursy i warsztaty (Dittfeld, 2004).

Zakres tematyczny wyżej wymienionych działań powinien obejmować:

- promowanie zdrowego stylu życia, w szczególności wśród kobiet ciężarnych;

- omówienie przebiegu nabywania mowy i języka wśród dzieci w pierwszych latach życia;

- omówienie najczęściej występujących wad wymowy oraz czynniki wpływające na ich występowanie;

- wczesna identyfikacja zaburzeń w komunikowaniu się;

- niepokojące objawy wad wymowy oraz czynniki towarzyszące;

- higienę głosu;

- konsultacje specjalistyczne w przypadku wystąpienia niepokojących objawów;

- zasady współpracy między specjalistami a pacjentami i ich rodzinami (Dittfeld, 2004).

Jak można zauważyć, profilaktyka logopedyczna, obok działań promujących i stymulujących wszechstronny rozwój językowy dzieci i młodzieży, to przede wszystkim wszelkie strategie wczesnej identyfikacji zaburzeń mowy oraz szybko podjęta interwencja. Zatem jest to profilaktyka interdyscyplinarna, wdrażana na 
różnych poziomach, której działania umożliwiają zapobieganie dalszym niepomyślnym skutkom w sytuacji, gdy problem logopedyczny już zaistniał (Gałkowski, Jastrzębowska, 2003).

Należy jednak pamiętać, że skuteczna profilaktyka logopedyczna wymaga działań kompleksowych realizowanych systemowo we współpracy z całym środowiskiem. Są to działania prewencyjne, które obejmują całą populację, w każdym momencie życia - od chwili narodzin do późnej starości. W placówkach edukacyjnych logopedyczne działania profilaktyczne odnoszą się nie tylko do dziecka, ucznia, jego opiekunów, lecz także do nauczyciela, który jest bardzo ważnym ogniwem wszechstronnej profilaktyki logopedycznej (Gałkowski, Jastrzębowska, 2003).

Pedagodzy, nauczyciele, a szczególnie wychowawcy bardzo dobrze znają możliwości i problemy swoich wychowanków. Zdają sobie również sprawę z potrzeby zacieśniania współpracy ze środowiskiem logopedycznym. W obecnym systemie jest to jednak utrudnione, ponieważ organizacja pracy logopedy skupia się w poradniach psychologiczno-pedagogicznych, do których rodzic z dzieckiem musi zgłosić się dobrowolnie. W szkołach podstawowych liczba godzin pracy specjalisty jest niewielka, a duża liczba uczniów powoduje, że na terapię w pierwszej kolejności uczęszczają uczniowie $\mathrm{z}$ aktualnym orzeczeniem lub opinią z poradni psychologiczno-pedagogicznej (Gałkowski, Jastrzębowska, 2003). Dlatego tak ważną rolę spełnia nauczyciel i podejmowane przez niego działania profilaktyczne. Wymusza to na nim rozwijanie własnego warsztatu zawodowego poprzez samokształcenie, podnoszenie kwalifikacji z zakresu profilaktyki i wczesnej interwencji logopedycznej.

Nauczyciele klas pierwszych znajdują się w bardzo trudnej sytuacji, ponieważ praca z dziećmi 6 - i 7-letnimi jest bardzo zróżnicowana, biorąc pod uwagę stopień opanowania mowy i umiejętności posługiwania się nią, a poziom rozwoju mowy i ewentualne zaburzenia mowy wpływają na psychiczne i społeczne przystosowanie dziecka do nowej sytuacji szkolnej i na jego harmonijne funkcjonowanie w klasie. Konieczne staje się wczesne rozpoznanie występujących u dzieci problemów wad językowych i zapewnienie im właściwej formy stymulacji oraz terapii. Wczesne rozpoznanie wad wymowy ma bowiem decydujące znaczenie dla skuteczności terapii logopedycznej (Błachnio, 2001).

Wszechstronność terapii logopedycznej obejmuje trzy stopnie oddziaływań: pierwotne (pierwszorzędowe), wtórne (drugorzędowe) i trzeciorzędowe. Oddziaływania pierwszorzędowe odnoszą się do działalności informacyjnej na temat zaburzeń artykulacyjnych i ograniczeń komunikacyjnych, oddziaływań, które 
sprzyjają rozwojowi mowy i prawidłowych nawyków artykulacyjnych czy niepokojących objawów. Kierowane są do całego społeczeństwa. Oddziaływania wtórne, w skład których wchodzą m.in. badania przesiewowe mowy, mają na celu wyodrębnienie grupy, która narażona jest na wystąpienie zaburzeń artykulacyjnych. Profilaktyczne oddziaływania trzeciorzędowe mają na celu wspomóc terapię logopedyczną, dzięki czemu uczeń uniknie trwałych, niepomyślnych konsekwencji zaburzenia artykulacyjnego (Węsierska, 2012).

W celu nawiązania dobrej współpracy między środowiskiem szkolnym a specjalistami niezbędne jest nie tylko udostępnienie informacji na temat mowy, ale także narzędzi, które umożliwiłyby sprawdzenie poziomu umiejętności komunikacyjnych. Narzędzia powinny być nieskomplikowane i ułatwiać pracę (Gałkowski, Jastrzębowska, 2003). Logopeda, współpracujący z przedszkolem, powinien instruować nauczycieli z zakresu najważniejszych wyznaczników świadczących o ewentualnych wadach, problemach ze słuchem oraz w przypadku potrzeby zapewnić o możliwości wykonania specjalistycznej diagnozy na terenie placówki (Dittfeld, 2004).

Popularne testy służące do oceny artykulacji to: „Logopedyczny test przesiewowy dla dzieci w wieku szkolnym" S. Grabiasa, M. Kurkowskiego i T. Woźniaka, wystandaryzowane narzędzia do badań artykulacyjnych: „Przesiewowy test logopedyczny” Z. Tarkowskiego, „Instrukcja do prowadzenia badań przesiewowych” D. Emiluty-Rozyi, H. Mierzejewskiej, P. Patys, „100-wyrazowy test artykulacyjny” E. Krajny, „KOLD - Karty Oceny Logopedycznej Dziecka” J. Gruba. Na rynku jest wiele dostępnych narzędzi do badania mowy: „Afaskala" A. Paluch, E. Drewniak-Wołoszyn, L. Mikoszy, test przeznaczony jest do badania mowy dzieci afatycznych. „Sprawdź, jak mówię” E. Stecko, kwestionariusz badania może służyć już do diagnozy noworodków, dzieci w okresie dziecięcym, przedszkolnym, a także tych powyżej siódmego roku życia. Przesiewowe testy logopedyczne nie stanowią pełnej diagnozy umiejętności nadawania dźwięków mowy, mają jedynie za zadanie wyodrębnienie grupy potencjalnych uczniów, którzy są narażeni na wady wymowy lub już posiadają problemy artykulacyjne czy trudności komunikacyjne. Badania przesiewowe mają prostą formę, a czas ich wykonania wynosi kilka minut. Dzięki prostocie możliwe jest korzystanie z nich przez osoby, które nie posiadają pełnych kwalifikacji logopedycznych, czyli przez nauczycieli, pedagogów, psychologów, lekarzy czy pielęgniarki. Badanie polega na nawiązaniu kontaktu werbalnego z osobą badaną, podstawową próbą jest prezentacja obrazków, osoba badana nazywa obrazki lub na ich podstawie rozmawia o danym przedmiocie, zjawisku (Węsierska, 2012). 
Dzięki tym działaniom możliwa jest ocena: zasobu słownictwa, umiejętność budowania dłuższych wypowiedzi słownych, ocena poprawności fleksyjnej, gramatycznej. W przypadku, gdy badany nie nawiązuje kontaktu werbalnego, ocenia się poziom rozumienia komunikatów i poleceń słownych. Badanie przesiewowe jest wstępną informacją, szczególnie ważną dla wychowawcy, który dzięki niemu na pełną informację na temat umiejętności uczniów, ich możliwości i ograniczeń, a w przypadku wątpliwości może skierować uczniów na dokładną diagnozę logopedyczną u specjalisty w szkole lub poinformować rodziców na temat dalszego postępowania przy podejrzeniu zaistniałego problemu (Węsierska, 2012).

Kolejnym działaniem, które może być realizowane wspólnie przez nauczycieli i logopedów, wraz z pozostałą kadrą jest tworzenie programów profilaktycznych. Ochrona zdrowia i profilaktyka od kilku lat jest priorytetowym kierunkiem działań Światowej Organizacji Zdrowia (WHO). W tym właśnie celu tworzone są programy profilaktyczne. Szkolne Programy Profilaktyki kierowane są do uczniów, rodziców i nauczycieli, mają na celu wyposażenie określonej grupy docelowej odbiorców w niezbędne kompetencje (Gaś, 1998).

Szkolny program profilaktyczny ma za zadanie uzupełnić program wychowawczy szkoły, zapewnić wszechstronny rozwój ucznia. Wychowanie i profilaktyka powinny być jednością. Nauczyciele w swojej pracy wychowawczej powinni więc zmierzać do tego, aby uczniowie:

- wszechstronnie rozwijali osobowość w wymiarze intelektualnym, psychicznym, społecznym, zdrowotnym, estetycznym, moralnym i duchowym;

- dążyli do osiągnięcia celów życiowych i wartości wyższych;

- przygotowali się do rozpoznawania wartości moralnych, mieli możliwość doskonalenia się;

- przygotowali się do spełniania określonych ról życiowych.

Aby program był adekwatny do potrzeb i problemów, niezbędna jest diagnoza oraz współpraca całego zespołu szkolnego, czyli specjalistów takich, jak: logopedzi, pedagodzy, psycholodzy z nauczycielami i wychowawcami (Szymańska, 2012).

Rekomendowane programy profilaktyczne znajdują się w Banku Rekomendowanych Programów Profilaktycznych, obecnie Ośrodka Rozwoju Edukacji w zakładce Wychowanie i Profilaktyka, Programy profilaktyczne, Bank programów zamieszczonych na stronie internetowej www.ore.edu.pl. W 2001 roku opublikowano pierwsze Standardy Jakości Edukacyjnych Programów. W polskich szkołach realizowane są również programy, które nie są umieszczone we wspomnianym Banku, ponieważ nie zostały poddane badaniom ze względu na 
wysokie koszty. Ponadto jest wiele tzw. projektów autorskich, realizowanych tylko w jednej szkole lub na terenie jednej gminy.

Przykładem autorskiego programu logopedycznego, realizowanego na terenie Rudy Śląskiej, jest program opracowany przez mgr Mariolę Foryś-Nikodem pod nazwą: „Ćwiczenia buzi i języka. Usprawnianie aparatu artykulacyjnego dzieci w wieku przedszkolnym". Program ma na celu uświadomienie nauczycieli, rodziców, jak ważne jest wczesne wspomaganie rozwoju. Prawidłowe funkcjonowanie dziecka zarówno motoryczne, jak i poznawcze zależy od określonych granic czasowych. Według autorki pierwsze lata życia są najcenniejszym czasem terapii. Stworzone przez pierwsze dwa do trzech lat podstawy poznawcze warunkują rozwój dziecka i sukces zabiegów terapeutycznych. Sukces jest jednak indywidualny i zależy od stopnia zaistniałej wady i możliwości rozwojowych dziecka (http://www.mp32.pl/cms/index.phpoption=com_content\&view=article\&id=20\& Itemid=25).

Kolejnym przykładem jest autorski program mgr Moniki Sawickiej-Komali „Coraz lepiej mówię” dla uczniów Szkoły Podstawowej w Wierzchowie. Program skierowany jest dla uczniów klas I-IV oraz przedszkolaków z wadami wymowy. W ramach realizacji programu odbyły się warsztaty, prelekcje, spotkania informacyjne poszerzające wiedzę rodziców i nauczycieli na temat profilaktyki wad wymowy. Planowane były zajęcia grupowe dla przedszkolaków i uczniów klas I-IV. Ewaluacja programu miała być dokonana na podstawie obserwacji uczniów $\mathrm{i}$ ich aktywności $\mathrm{w}$ trakcie odbywania terapii oraz prowadzonej indywidualnej dokumentacji (http://www.szkolawierzchowodworzec.eduszkoly.pl/wpcontent /uploads/2014/05/program-profilaktyki-i-terapii-logopedycznej).

W tworzeniu programów profilaktycznych bierze udział wiele osób ze środowiska szkolnego, dzięki współpracy wnikliwie analizują możliwości, potrzeby i trudności swoich uczniów. Działalność profilaktyczna, obejmująca środowisko szkolne i rodzinne, ma na celu zapewnienie harmonijnego rozwoju ucznia.

\section{POSTAWA NAUCZYCIELA WSPIERAJĄCEGO TERAPIĘ LOGOPEDYCZNĄ UCZNIA}

Każdy nauczyciel powinien być wzorem dla swojego wychowanka, dlatego tak ważna jest samoobserwacja przez pedagogów i ich własna refleksja nad językiem, jakim się posługują. Staranna mowa i adekwatne ujmowanie treści zachęca uczniów do uważnego słuchania i analizowania poruszanego tematu 
(Wójtowicz, 1997). Mowa nauczyciela musi być poprawna pod względem artykulacyjnym, a język cechować się naturalnością, która zachęca wychowanków do spontaniczności w mówieniu. Ton i siłę głosu pedagog powinien dostosowywać do miejsca i przekazywanych treści, tempo mowy dostosowane do możliwości percepcyjnych dzieci (Wójtowicz, 1997), które można ustalić podczas przesiewowych badań mowy. Jak podkreśla Węsierska, ścisła współpraca nauczycieli, logopedów i najbliższego środowiska dziecka wpływa na rozwój mowy ucznia. Wychowanek powinien mieć prezentowany właściwy wzorzec mowy, a nauczyciel swój warsztat pracy powinien uzupełniać poprzez podnoszenie kwalifikacji z zakresu profilaktyki i wczesnej interwencji logopedycznej (Węsierska, 2007).

$\mathrm{W}$ przypadku występowania w klasie uczniów z wadami wymowy ważna jest postawa nauczyciela i jego świadomość, że od jego działań zależy samopoczucie dziecka. Istotne jest, by wspierał on terapię zaplanowaną przez logopedę i stosował w swojej praktyce pedagogicznej działania usprawniające mowę, stosując właściwe ćwiczenia i zabawy. Ogromnym atutem jest umiejętność nawiązania kontaktów z dziećmi, humor, życzliwość, wyrozumiałość, umiejętność wczucia się w sytuację dziecka. Należy pamiętać, że często nauczyciel w przedszkolu i klasach najmłodszych staje się bardzo ważną osobą dla dziecka, niekiedy zdobywa większe uznanie i autorytet od rodzica. Wychowawca w ten sposób powinien wprowadzać trzeciorzędowy etap profilaktyki logopedycznej, a dzięki ścisłej współpracy z logopedą motywować wychowanków do podejmowania dalszych czynności terapeutycznych, a także podtrzymywać osiągnięte sukcesy (Węsierska, 2007).

Ważne jest, by nauczyciel w kontakcie z dzieckiem z wadą wymowy lub trudnościami komunikacyjnymi (np. przy jąkaniu wczesnodziecięcym), przestrzegał następujących zasad:

- zachowanie spokojnego i wolnego tonu wypowiedzi, aby nie stwarzać okazji do pośpiesznego budowania zdań;

- reagowanie na cały komunikat dziecka, a nie skupianie się tylko na błędach artykulacyjnych;

- nie należy wyliczać błędów dziecka podczas budowania wypowiedzi;

- nie mówić za ucznia i nie odpowiadać za niego na pytania;

- umożliwiać czytanie i recytacje wierszy w parze;

- nie polecać dziecku, aby powtórzyło wypowiedź, mówiło wolniej, pomyślało, zanim powie;

- nie robić z wady czy trudności ośrodka zainteresowania;

- reagować na akty komunikacyjne w identyczny sposób, gdy dziecko mówi z błędami lub gdy mówi bez nich; 
- nie wyłączać dziecka z aktywności klasowej;

- pomagać w budowaniu poczucia własnej wartości, dostrzegać pozytywne cechy;

- pozwalać uczniowi wybrać formę wypowiedzi ustną lub pisemną (Byrne 1989).

W ten sposób nauczyciel będzie wspierał terapię logopedyczną, a dziecku zapewni poczucie bezpieczeństwa. Wspomaganie przy budowaniu pewności siebie w pozytywny sposób wpłynie na efektywność terapii logopedycznej wychowanka (Dittfeld, 2004).

\section{PODSUMOWANIE}

Harmonijny rozwój dziecka możliwy jest poprzez integrację różnych czynników, a w tym dzięki współpracy środowiska domowego i szkolnego. Wiele pisze się o prawidłowych relacjach rodziny z nauczycielami, dlatego też bardzo istotne jest zwrócenie uwagi na prawidłowe relacje wychowawców ze specjalistami współpracującymi ze szkołą. Integralne działanie, jasny i czytelny przekaz informacji pozwala na przejrzystą wymianę informacji, która wpływa na rozwój dziecka i zapewnia jego prawidłowy przebieg. Fragmentaryczne deficyty rozwojowe, a bez wątpienia są nimi wady wymowy, wpływają na poziom funkcjonowania dziecka w szkole i jego zachowanie. Dziecko, które nie uzyskało w odpowiednim czasie pomocy ze strony dorosłych, nie mogąc podołać obowiązkom, wycofuje się z aktywności poznawczej, ogranicza swe zainteresowania, co jest powodem pewnego zahamowania rozwoju. Przed nauczycielem klas początkowych stoi zatem ważne zadanie wczesnego rozpoznania takich uczniów, uświadomienia rodzicom faktu konieczności terapii logopedycznej w profilaktyce trudności szkolnych. Dzięki posiadanej wiedzy z zakresu logopedii może niejednokrotnie lepiej niż rodzice ocenić stan mowy dziecka. W związku z tym wcześniej zauważa konieczność podjęcia intensywnych zabiegów profilaktycznych lub korygujących wady mowy. Młodszy wiek szkolny to wręcz alarmujący „dzwonek” na reakcję rodziców oraz nauczycieli i pomoc wszędzie tam, gdzie potrzebna jest fachowa diagnoza i terapia logopedyczna. Dlatego tak ważne jest stworzenie większych obszarów współpracy. Logopeda ma za zadanie wykonać diagnozę logopedyczną, zaś profilaktyką powinny zająć się osoby, które mają kontakt z dzieckiem na co dzień, czyli nauczyciele lub rodzice. Czasem wystarczy odrobina empatii i wsparcia, polegającego na pokazaniu nauczycielom, pedagogom 
oraz wszystkim osobom mającym kontakt z dziećmi, w jaki sposób owe zabiegi może przeprowadzić ktoś, kto nie jest logopedą, a dobro dziecka odgrywa dla niego pierwszoplanową rolę.

\section{BIBLIOGRAFIA}

Bogdanowicz, M., SzewczyK, M. (2011). Metoda Dobrego Startu: od stowa do zdania, od zdania do tekstu: wspomaganie rozwoju dzieci, zwłaszcza z opóźnionym rozwojem mowy i wada stuchu. Gdańsk: Wydawnictwo Harmonia.

BŁACHNIO, K. (2001). Vademecum logopedyczne: dla studentów pedagogiki. Poznań: Wydawnictwo Uniwersytetu Adama Mickiewicza.

CieszyŃSKA, J., KoRENDO, M. (2015). Wczesna interwencja terapeutyczna. Stymulacja rozwoju dziecka od noworodka do 6. roku życia. Kraków: Wydawnictwo Edukacyjne.

GAŚ, Z.B. (1998). Psychoprofilaktyka. Procedury konstruowania programów wczesnej interwencji. Lublin: Wydawnictwo UMCS.

Grabias, S., KURKOwSKI M. (2014). Logopedia. Terapia zaburzeń mowy. Wyd. II. Lublin: Wydawnictwo UMCS.

DitTFeld, B. (2004). Spróbujmy mówić razem. Program profilaktyki logopedycznej (dla przedszkoli, klas ksztacenia zintegrowanego i integracyjnego). Kraków: Oficyna Wydawnicza „Impuls”.

GaŁkowski, T., JastrzęBowska, G. (2003). Logopedia - pytania i odpowiedzi. Podręcznik akademicki. Opole: Wydawnictwo Uniwersytetu Opolskiego.

KURCBART, A. (2010). Komunikacja interpersonalna jako podstawowe narzędzie w pracy z wychowankiem - perspektywa psychologiczna. W: K. KALETA, J. Mróz (red.), Psychologiczne aspekty trudności w wychowaniu dzieci z zaburzeniami rozwoju i zachowania (s. 105-120). Kielce: Wydawnictwo Pedagogiczne ZNP.

MinCZAKIEwiCZ, E.M. (2015). Sytuacja szkolna uczniów z zaburzeniami mowy w klasie i grupie rówieśniczej. W: B. WinczuRA (red.), Dzieci o specjalnych potrzebach komunikacyjnych. Diagnoza - edukacja - terapia (s. 237-250). Kraków: Oficyna Wydawnicza „Impuls”.

NęCKA, E., OrZechowski, J., SzYmura, B. (2006). Psychologia poznawcza. Warszawa: Wydawnictwo Naukowe PWN.

SKOREK, E. M. (2001). Oblicza wad wymowy. Warszawa: Wydawnictwo Edukacyjne Żak.

SoŁtys-ChmiElowicz, A. (2008). Zaburzenia artykulacji. Teoria i praktyka. Kraków: Oficyna Wydawnicza „Impuls”.

Szymańska, J. (2012). Programy profilaktyczne. Podstawy profesjonalnej psychoprofilaktyki. Warszawa: Centrum Rozwoju Edukacji.

WĘSIERSKA, K. (2012). Profilaktyka logopedyczna w ujęciu systemowym. W: K. WĘSIERSKA (red.), Profilaktyka logopedyczna w ujęciu systemowym. T. 1 (s. 25-47). Katowice: Wydawnictwo Uniwersytetu Śląskiego.

WęSIERSKA, K. (2007). Profilaktyka logopedyczna w edukacji przedszkolnej. Wychowanie na co dzień, 6, 8-11.

Wóstowicz, A. (1997). O wychowaniu językowym. Warszawa: Wydawnictwo Wytwórnia Pomocy Dydaktycznych.

http://www.mp32.pl/cms/index.phpoption=com_content $\&$ view=article $\&$ id $=20 \&$ Itemid $=25$ (dostęp: 25.12.2018).

http://www.szkolawierzchowodworzec.eduszkoly.pl/wpcontent/uploads/2014/05/program-profilaktyki -i-terapii-logopedycznej (dostęp: 25.12.2018). 


\title{
PROFILAKTYKA LOGOPEDYCZNA W PRAKTYCE NAUCZYCIELA EDUKACJI WCZESNOSZKOLNEJ
}

\author{
Streszczenie
}

Prawidłowy rozwój mowy i języka dziecka zaczyna się już w okresie prenatalnym. Warunki środowiskowe wpływają na umiejętność poprawnego nabywania dźwięków mowy przez dziecko, poznawania reguł gramatyki, wzbogacania słownictwa biernego i czynnego. Uczeń edukacji wczesnoszkolnej powinien opanować szereg umiejętności, które ułatwią mu komunikację oraz bezpośrednio wpływają na prawidłowy rozwój psychospołeczny. Zintegrowane działania kadry nauczycielskiej i specjalistów pozwalają na wyodrębnienie podopiecznych z wadami wymowy oraz ich korygowanie poprzez odpowiednio dobraną terapię logopedyczną. Zagwarantowanie dzieciom i młodzieży warunków do harmonijnego rozwoju mowy, sprawności językowej i możliwie najpełniejszych kompetencji w zakresie komunikacji interpersonalnej jest najlepszą inwestycją na przyszłość. Dlatego tak ważna jest działalność profilaktyczna, która jest jednym z najistotniejszych uwarunkowań efektywnego systemu opieki logopedycznej, opierającego się na nawiązywaniu skutecznej współpracy logopedów z pedagogami w wyniku wdrażania strategii prewencyjnych w systemie edukacji.

Słowa kluczowe: logopedia; edukacja wczesnoszkolna; uczeń ze specjalnymi potrzebami komunikacyjnymi; wady wymowy; profilaktyka.

\section{SPEECH THERAPY PREVENTION IN EARLY EDUCATION TEACHER'S WORK}

$$
\text { S u m m a ry }
$$

The right development of speech and language of a child begins in the prenatal period. Environmental conditions influence the ability of a child to acquire the speech sounds, learn grammar rules, enrich his/her passive and active vocabulary. Early education pupil should learn a number of skills which will facilitate the process of communication and will directly influence the right psychological and social development of a child. Integrated actions of teaching staff and specialists allow to find the children with speech defects and allow the correction of the defects by using particular sorts of stimulation. It seems to be the best possible investment to guarantee the children and the youth best conditions for harmonious speech development, language skills and possibly, providing them with the best competence in interpersonal communication. That is why preventive activity is so meaningful as it is one of the most important conditions of effective system of speech therapy prevention. The system should be based on effective cooperation of speech therapists and pedagogues who implement preventive strategies to education system.

Key words: speech therapy; early school education; a pupil with special communicative needs; speech defects; prevention. 